\title{
Is spring burning a viable management tool for species-rich grasslands?
}

Per Milberg, Brenda Akoto, Karl-Olof Bergman, Håkan Fogelfors, Heidi Paltto and Malin

Tälle

\section{Linköping University Post Print}

\section{Tweet}

N.B.: When citing this work, cite the original article.

Original Publication:

Per Milberg, Brenda Akoto, Karl-Olof Bergman, Håkan Fogelfors, Heidi Paltto and Malin Tälle, Is spring burning a viable management tool for species-rich grasslands?, 2014, Applied Vegetation Science, (17), 3, 429-441.

http://dx.doi.org/10.1111/avsc.12091

Copyright: Wiley: 12 months http://eu.wiley.com/WileyCDA/

Postprint available at: Linköping University Electronic Press http://urn.kb.se/resolve?urn=urn:nbn:se:liu:diva-109111 


\section{Is spring burning a viable management tool for species-rich grasslands?}

Per Milberg, Brenda Akoto, Karl-Olof Bergman, Håkan Fogelfors, Heidi Paltto, Malin Tälle

Milberg, P. (corresponding author per.milberg@liu.se), Akoto, B. (brenda2jr@yahoo.com), Bergman, K.-O. (karl-olof.bergman@liu.se), Paltto, H. (heidi.paltto@liu.se), Tälle, M. (malin.talle@gmail.com): IFM Biology, Conservation Ecology Group, Linköping University, SE-581 83 Linköping, Sweden

Fogelfors, H. (hakan.fogelfors@slu.se): Department of Crop Production Ecology, Swedish University of Agricultural Sciences, Box 7043, SE75007 Uppsala, Sweden

3 Tables

5 Figures

1 Appendix

Running title: Burning and grassland management

60 word "summary of what is exciting about the MS":

Within the context of evidence-based conservation, we provide clear evidence that spring burning is not a viable long-term alternative to grazing or mowing. We do this by using odds ratios for finding indicator species, rather than using more traditional methods of vegetation analyses, and by meta-analyses of the outcomes from 11 field trials. 


\begin{abstract}
Question: The management of species-rich semi-natural grasslands, a fragmented and threatened vegetation type in Europe, involves costs. Mowing is expensive and grazing can be difficult to achieve and maintain for logistical reasons. Is annual spring burning, potentially cheaper than mowing and grazing, a viable management tool for species-rich grasslands?
\end{abstract}

Location: Long-term field trials in 11 grasslands in southern Sweden.

Methods: We calculated the odds for a species being an indicator of good management, an indicator of poor management, and an indicator of nitrogen influence in spring-burnt plots, grazed plots, and annually mowed plots. Odds ratios contrasting spring-burnt plots with grazed plots and spring-burnt plots with mowed plots were subjected to meta-analyses in which we compared the odds ratios after 1, 8, and 14 spring burns. For a single trial, we also analysed data after 1, 8, 14, 28, and 39 spring burns.

Results: Compared with mowed and grazed plots, the odds of the four different indicators of good management decreased in spring-burnt plots, while the odds for the two indicators of poor management increased. There was no trend in the two indicators of excess nitrogen. Therefore, the conservation value of vegetation in spring-burnt plots becomes impoverished over time relative to traditional management.

Conclusions: Spring burning is not an appropriate long-term management method if the aim is to maintain the conservation value of the vegetation in traditionally managed semi-natural grasslands.

Keywords Grass; fire; grazing; indicators; meta-analysis; mowing; odds ratio; semi-natural grassland, Sweden

Nomenclature Karlsson 1998

Abbreviation $\log \mathrm{OR}=$ logarithm of odds ratio 


\section{Introduction}

Semi-natural grasslands are one of the most species-rich habitats in the agricultural landscape of Europe; these areas contain a high diversity of plant and animal species (Isselstein et al. 2005). For example, approximately 600 species of plants can be found in this type of habitat in Sweden (Svensson 1988). Traditionally, many species-rich grasslands have been used by farmers as hay meadows that are cut for winter fodder. More recently, these lands have been used as pastures for grazing. In addition to high biodiversity, semi-natural grasslands provide ecosystem services, such as pollinators for the surrounding landscape, and carbon sequestration (Minns et al. 2001; Öckinger \& Smith 2006; Franzen \& Nilsson 2008; De Deyn et al. 2011; Wrage et al. 2011).

Over the last century, the application of inorganic fertilisers has steadily increased in many grassland areas to increase yields. Because many plants adapted to semi-natural grasslands are not able to compete with species growing in fertilised grasslands, the species composition changes in such a way that the areas are no longer defined as semi-natural grasslands. In addition, ceased management of semi-natural grasslands (Lindborg \& Eriksson 2004) has resulted in the conversion of grasslands into forests through tree planting or natural succession (Milberg 1995; Hansson \& Fogelfors 2000).

It is costly to manage grassland areas by mowing (Schreiber et al. 2009). Due to the decreasing numbers of the appropriate types of cattle, it is increasingly difficult to ensure animals for conservation grazing even if the economic funding is available (e.g., Kumm 2003). In addition, the funds available for management with traditional methods are limited. Therefore, there is a need for alternative and cheaper management methods.

Burning has been considered as an alternative to mowing and grazing, as it is less labour-intensive and thereby provides a cheaper way to manage semi-natural grasslands (Larsson 2007; Sundh 2009; Larsson \& Persson 2012). Spring burning has conventionally been used to remove accumulated dead plant material and to reduce the encroachment of woody plants in boreal grasslands (Antonsen \& Olsson 2005). A few studies have examined the vegetation and species composition after the introduction of spring burning and have noted a change in composition (Hansson \& Fogelfors 2000; Wahlman \& Milberg 2002; Moog et al. 2002; Antonsen \& Olsson 2005). Thus far, no studies have given full consideration to spring burning as a potential viable management tool for semi-natural grasslands. This assessment can be achieved by evaluating 
the floral components that indicate high- or poor-quality semi-natural grasslands.

When providing decision support for managers, a particular challenge is the assembly of complex information about the vegetation composition from various places and the interpretation of the "best available evidence". If "evidence-based conservation" (Sutherland et al. 2004; Pullin \& Knight 2004) is to ever live up to its promise, at least when dealing with the management of plant communities or animal assemblages, a critical step is to find biologically relevant indicators that can be used in metaanalyses.

The aim of the present study was to examine whether burning, compared with the traditional management methods of mowing and grazing, maintains the desired composition of grassland vegetation in the long run. What is currently desired in Sweden are species typical of unfertilised and traditionally managed land from (Ekstam \& Forshed 1996, 2000). We used data from 11 field trials in southern Sweden, and groups of indicator species to describe the composition of the vegetation. This included indicator species of good management, indicator species of poor management, and indicator species of excess nitrogen. We calculated the odds of finding these indicators in spring-burnt plots and in plots that had been grazed or mowed annually. Using these odds, we made vegetation data comparable between trials and years (during which survey methods varied) and over trials differing greatly in species composition. The odds ratios (Rita \& Komonen 2008) that contrasted spring-burnt plots with grazed plots and spring-burnt plots with mowed plots were subjected to meta-analyses in which we compared three time points (a maximum of 14/15 spring burns) for 11 trials. For one of these trials that is still running, we used five time points (a maximum of 39 spring burns). If annual spring-burns are to be recommended, the odds ratios should stay the same or change in a desirable direction (i.e., an increase in good management indicators and/or a decrease in poor management and excess $\mathrm{N}$ indicators should be seen).

\section{Methods}

\section{Study sites}

In total, we studied 11 experimental grassland trials situated at nine locations in southern Sweden (Fig. 1). Two of the locations, Ekenäs and Tagel, had two experimental trials each (Table 1). The trials composed a long-term field experiment established in the early 1970s with the aim of comparing different management methods for semi-natural grassland 
vegetation. The sites had different land-use history and varied in nutrient and moisture conditions (Hansson 1991). The vegetation at the majority of the 11 sites is of the mesic meadow type (Table 1). In most cases, the vegetation in the trials was surveyed on three occasions (Table 1). In addition, the trial at Sättra, that is still running, was surveyed in 2000 (Wahlman \& Milberg 2002) and within the present study in 2011.

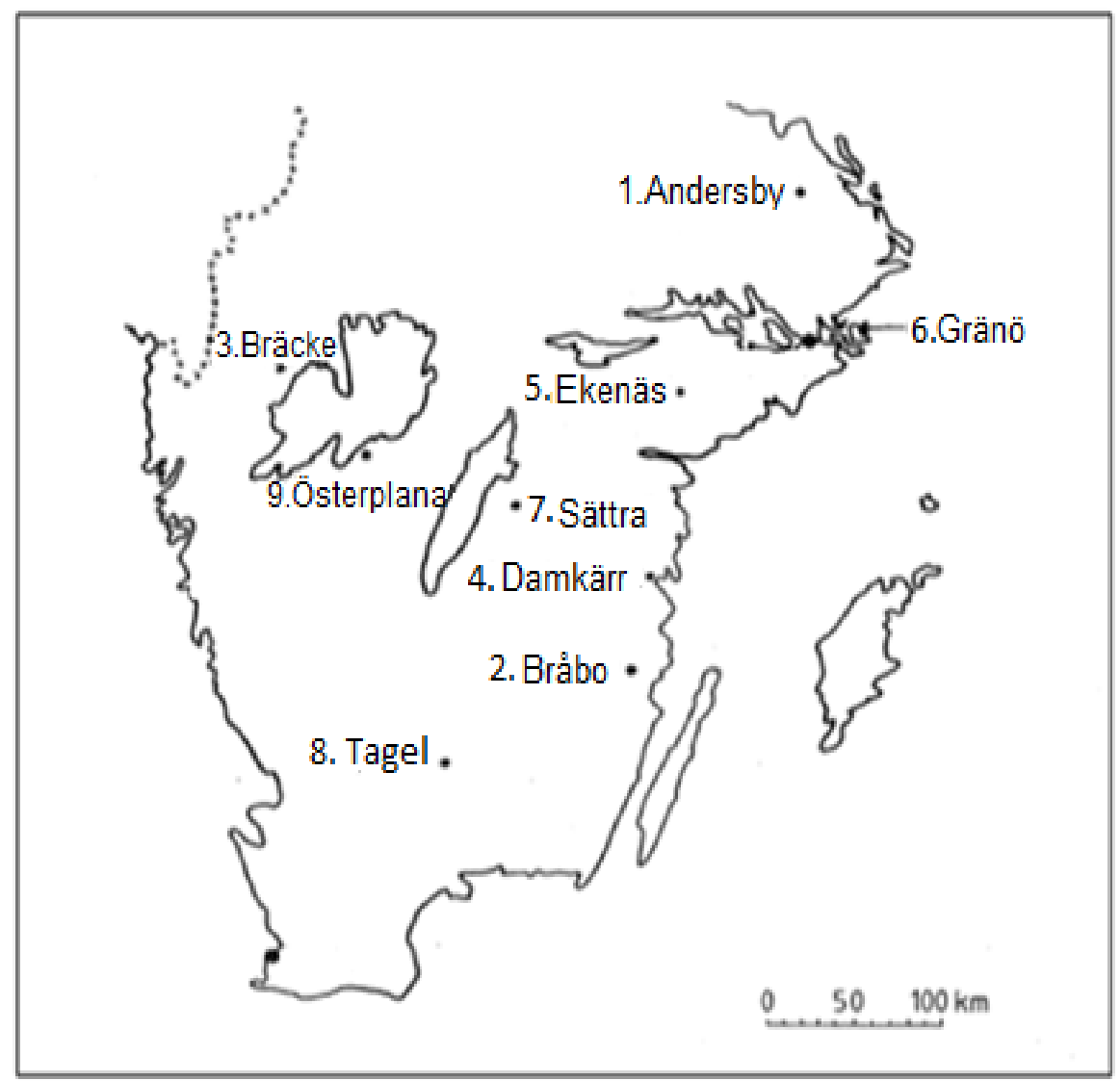

Fig. 1. Study locations in southern Sweden. At two of the locations, Ekenäs and Tagel, two trials were placed. 
Table 1. General description and years of inventory of the experimental sites established in southern Sweden for the comparison of management methods in seminatural grassland vegetation. All management trials started in the spring of 1973, with the exception of the two trials at Ekenäs that started in the spring of 1975.

\begin{tabular}{|c|c|c|c|c|c|c|c|c|c|c|}
\hline & \multirow[b]{2}{*}{ Site } & \multicolumn{7}{|c|}{ Year of Inventory } & \multirow[b]{2}{*}{ Vegetation type } & \multirow[b]{2}{*}{ Soil category } \\
\hline & & $\begin{array}{l}\bar{m} \\
\stackrel{n}{\sigma}\end{array}$ & 占 & 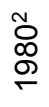 & 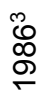 & 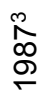 & 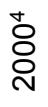 & ז্ণ & & \\
\hline 1. & $\begin{array}{l}\text { Andersby, } \\
\text { Dannemora }\end{array}$ & $x$ & & $x$ & $\mathrm{x}$ & & & & moist meadow & humus rich light clay \\
\hline 2. & Bråbo, Oskarsham & $x$ & & $x$ & $x$ & & & & mesic meadow & rock moraine \\
\hline 3. & Bräcke, Åmål & $x$ & & $x$ & $x$ & & & & mesic meadow & silt \\
\hline 4. & Damkärr, Gamleby & $x$ & & & $x$ & & & & mesic meadow & humus rich silt \\
\hline \multirow[t]{3}{*}{5.} & Ekenäs, Flen & & & & & & & & & \\
\hline & a Moist & & $x$ & & $x$ & & & & moist meadow & $\begin{array}{l}\text { highly humus rich } \\
\text { light clay }\end{array}$ \\
\hline & b Mesic & & $x$ & $x$ & $x$ & & & & $\begin{array}{l}\text { dry-mesic } \\
\text { meadow }\end{array}$ & humus rich loamy \\
\hline 6. & Gränö, Värmdö & $x$ & & & $x$ & & & & moist meadow & slightly humus rich silt \\
\hline 7. & Sättra, Ödeshög & $x$ & & $x$ & $x$ & & $x$ & $x$ & mesic meadow & slightly clayey sand \\
\hline \multirow[t]{3}{*}{8.} & Tagel, Alvesta & & & & & & & & & \\
\hline & a. Mesic & $x$ & & $x$ & $x$ & & & & mesic meadow & rocky sand \\
\hline & b. Former field & $x$ & & & & $x$ & & & mesic meadow & - \\
\hline 9. & Österplana, Götene & $x$ & & $x$ & $x$ & & & & dry meadow & gravelly clay loam \\
\hline
\end{tabular}

${ }^{1}$ Steen 1976

${ }^{2}$ Fogelfors 1982

${ }^{3}$ Hansson 1991

${ }^{4}$ Wahlman \& Milberg 2002

The trial at Sättra is within a nature reserve located approximately $55 \mathrm{~km}$ WSW of Linköping in the county of Östergotland in southern Sweden $\left(58^{\circ} 16^{\prime} \mathrm{N}, 14^{\circ} 49^{\prime} \mathrm{E} ; 19\right.$ ha in size). The reserve consists of species-rich meadows and pastures with stands of deciduous trees, of which Quercus robur is the most common. Mowing is presumed to have occurred in this area for several hundred years (Hansson 1991); the area was grazed by cattle in the 10-15 years prior to the initiation of the field experiment in the early 1970s (Wahlman \& Milberg 2002). Apart from cattle, the area has also been grazed by horses.

\section{Experimental design}

The long-term experiments set up at the 11 sites were designed to assess the changes in vegetation resulting from the introduction of six new management methods compared with continued grazing. The methods examined were annual mowing, mowing every third year, 
annual spring burning, the mechanical removal of woody plants, herbicide treatment of woody plants, and an untreated control. The management methods for all sites were applied to treatment plots of $5 \mathrm{~m}$ x $20 \mathrm{~m}$. Treatment plots were set within a randomised block design with two replicates. All of the plots at a site, with the exception of those that were grazed, were enclosed within a fence. In the present study, only three of the seven management methods were evaluated. The methods examined here were annual mowing, annual spring burning, and grazing. Burning was done in March or April after the snowmelt but before the onset of growth. The plots that were mowed once a year were mowed in late July or early August. The grazing plots were grazed by cattle and/or horses.

In the present study, we collated data from fieldwork conducted in 1973 (most trials; Steen 1976), 1975 (2 trials; Steen 1976), 1980 (most trials; Fogelfors 1982), 1986 (all except 1 trial; Hansson 1991), and 1987 (1 trial; Hansson 1991). For the experimental site at Sättra (Table 1), we used unpublished records from a study conducted in 2000 (Wahlman \& Milberg 2002) and collected new data in the field in 2011.

\section{Vegetation sampling at the 11 sites}

Fieldwork was conducted in July, before the annual mowing, with the exception of the survey of Sättra in 2000 that was conducted in September.

Vegetation sampling was carried out using different methods over various years. In many of the early surveys, the whole treatment plot was sampled. In two surveys (Bräcke, Ekenäs/Moist), the treatment plot was divided into two subplots that were surveyed separately. In some experiments, either three (Bråbo) or five (Andersby, Österplana; Steen 1976) $1-\mathrm{m}^{2}$ subplots per treatment plot were surveyed. In the $1980 \mathrm{~s}$ (Fogelfors 1982, Hansson 1991) and in 2011, five fixed 1- $\mathrm{m}^{2}$ subplots were used (except in Bräcke, where six subplots were used). In the Sättra experiment surveyed in 2000 , the majority of the treatment plots were covered by the $1520.5-\mathrm{m}^{2}$ subplots that were used (Wahlman \& Milberg 2002). To make the data from this trial comparable over year, we merged the data from adjacent subplots to create five $1-\mathrm{m}^{2}$ subplots; these subplots were located as close as possible to the fixed plots used previously.

Presence-absence data were gathered in some years, and coverage data were collected in others. The cover percentage was surveyed in the majority of plots, while the Hult-Sernander-duRietz scale was used for the 1- $\mathrm{m}^{2}$ subplots (Steen 1976, Fogelfors 1982 \& Hansson 1991). 
Regardless of the study design, we used presence-absence data from the subplots if available; otherwise, presence-absence data from the treatment plots were used.

\section{Classification of plant species}

To be able to compare data from different sites and collected with different methods, we simplified species data by using existing indicator systems that had classified grassland species as indicators. There are a number of potential indicator systems, and even if there is often substantial overlap among their species lists, the selection of system might influence the results. Therefore, we decided to include several potential systems. As indicator systems work best in their area of geographic origin (e.g. Jansson et al. 2009), and when used for their intended purpose, we selected only systems that were specifically targeting species-rich grasslands in southern Sweden and that were welldocumented (Table 2). Species were consequently recorded as (i) indicators of good management in grasslands, (ii) indicators of a poor management, (iii) indicators of excess nitrogen (Appendix).

Table 2. Overview of the indicator species classifications used and the percentage of subplots where indicator species occurred in 1986-87.

\begin{tabular}{lcccc}
\hline & $\begin{array}{c}\text { Number of indicator } \\
\text { species, of 312, occurring in } \\
1986 / 87\end{array}$ & $\begin{array}{c}\text { Grazing } \\
(128 \\
\text { subplots })\end{array}$ & $\begin{array}{c}\text { Mowing } \\
(112 \\
\text { subplots) }\end{array}$ & $\begin{array}{c}\text { Burning } \\
(112 \\
\text { subplots })\end{array}$ \\
\hline $\begin{array}{l}\text { Total number of occurrences in subplots } \\
\text { Indicators of good management }\end{array}$ & & 2270 & 2080 & 1418 \\
$\quad$ Bertilsson \& Paltto 2003 & 52 & & & \\
Ekstam \& Forshed 1992 & 53 & 81.3 & 85.7 & 58.9 \\
Larsson \& Ekstam 1987 & 45 & 80.5 & 83.0 & 58.9 \\
EPA 2011 & 55 & 74.2 & 77.7 & 55.4 \\
Indicators of poor management & 7 & 82.0 & 86.6 & 63.4 \\
Bertilsson \& Paltto 2003 & 56 & & & \\
Ekstam \& Forshed 1992 & & 82.8 & 81.3 & 82.1 \\
Indicators of excess N & & 99.2 & 100.0 & 92.9 \\
Bertilsson \& Paltto 2003 & 24 & & & \\
Ekstam \& Forshed 1992 & 35 & 98.4 & 95.5 & 94.6 \\
\hline
\end{tabular}

The indicator systems of Bertilsson \& Paltto (2003) were designed specifically for the evaluation of the grazing management status in grasslands and were devised for the province of Västergötland (Österplana is situated in this province, Fig. 1). The classification system of Larsson \& Ekstam (1987) was devised to assist in the development of a national inventory of species-rich grasslands. The system we call EPA 
(2011) is national and is based on the species listed for the defining vegetation types in Natura 2000. EPA (2011) included all of the species typical for one or more grassland types (Codes 6210, 6230, 6270, 6410, 6510,6530 , and 9070, according to the Council Directive 92/43/EEC on the Conservation of natural habitats and of wild fauna and flora).

The detailed system of Ekstam \& Forshed (1992), which is widely used by practitioners, does not provide a simple classification but instead places species in a nitrogen availability gradient (three classes) and consider the rate at which a species is lost during the secondary succession from grassland to forest (four classes). Hence, practitioners have simplified this system by merging classes, as did we. We considered indicators of good management to be those lost early in succession (classes A and B) and those that grow on sites poor in nitrogen (N1). Furthermore, the indicators of poor management were defined as species of late successional phases (classes $\mathrm{C}$ and $\mathrm{D}$ ) in nutrient-poor sites or sites with moderate levels of nitrogen (N1, N2). Finally, the indicators of excess $\mathrm{N}$ were species of all successional phases (classes A-D) in nitrogen-rich sites (N3).

Although the $\mathrm{N}$ classes of Bertilsson \& Paltto (2003) and Ekstam \& Forshed (1992) are unique systems, there is resemblance with the Ellenberg $\mathrm{N}$ numbers. In our case, the average Ellenberg $\mathrm{N}$ for the excess $\mathrm{N}$ indicators by Bertilsson \& Paltto (2003) was 6.5 (SD 1.37) and the remaining species 3.8 (1.98). Corresponding values for Ekstam \& Forshed (1992) N3 were 6.3 (1.18) and 3.7 (1.61) for the remaining species.

\section{Statistical analyses}

We compared the odds for the indicators between (i) the burning and mowing treatments and (ii) between the burning and grazing treatments. By using odds ratios, the differences in sampling methods and differences in the vegetation composition between trials can be overcome to some extent. Furthermore, the odds ratio is an excellent variable to use in meta-analysis. The following two separate analyses were conducted: 1) an analysis of the entire data set including all 11 trials and 2) an analysis of the data set from one of the two blocks at the Sättra field trial, which had a longer follow-up period (in the other block, both grazing and burning treatments had failed).

For each group of indicators, we first calculated either the total number of indicator species per subplot or the total number of indicator species per treatment plot (when subplots had not been used). Similarly, we calculated the total number of recorded non-indicator species, i.e., all 
other species in the subplot or treatment plot. We then summed the numbers of indicators (and non-indicators) in all subplots per treatment plot (if subplots were surveyed); this measure reflects the frequency of the indicator species (and non-indicator species) in each treatment plot.

To compare the burning treatment with the mowing and grazing treatments (Mengersen et al. 2013), a random effects meta-analysis was performed using Comprehensive Meta-analysis version 2 (Biostat, Inc. 2006, www.meta-analysis.com).

The effect sizes were measured as log OR (odds ratio):

$\log \mathrm{OR}=\log [(\mathrm{A} * \mathrm{D}) /(\mathrm{B} * \mathrm{C})]$

where

$\mathrm{A}=$ the frequency of indicators in the burning treatment

$\mathrm{B}=$ the frequency of non-indicators in the burning treatment

$\mathrm{C}=$ the frequency of indicators in the mowing or grazing treatments

$\mathrm{D}=$ the frequency of non-indicators in the mowing or grazing treatments

Log OR was calculated by contrasting the two relevant treatment plots per block, meaning that each trial contributed two entries, one per block, into the meta-analysis.

A meta-regression analysis was also conducted using the same software. This analysis considered the number of years since the onset of the trail as the covariate. Apart from the main outcome, we also grouped trials for the 1986/7 follow-up according to the vegetation type using the following three broad groups (Table 1): moist $(\mathrm{N}=3$ trials), mesic $(\mathrm{N}=6)$, and dry \& dry-mesic $(\mathrm{N}=2)$.

\section{Results}

In total, the data considered in the present study involved 312 species of plants. Of these, 245 were recorded in the 1986/87 inventory when all 11 trials were surveyed by using five (or six) subplots per treatment plot. The indicator systems for good management made up 14$20 \%$, indicators of poor management made up 3-22\%, and indicators of excess $\mathrm{N}$ made up $13-18 \%$ of these 245 species (see Table 2, Appendix $\mathrm{S} 1)$.

Management outcomes at the 11 experimental sites The odds for the indicators of good management decreased over time in the burnt plots compared to the mowed and grazed plots; this difference was apparent 
after seven and 13 years (Fig. 2A, B). This decreasing trend was most pronounced when burning was compared with mowing (Fig. 2A, B). As was expected, the clarity of the trend varied with the indicator system examined. The clearest pattern emerged from the systems targeting management (Bertilsson \& Paltto 2003, Ekstam \& Forshed 1992; Fig. $2 \mathrm{~A}, \mathrm{~B}$ ) compared to the systems used for vegetation classification (Fig. $2 \mathrm{~A}, \mathrm{~B})$. 

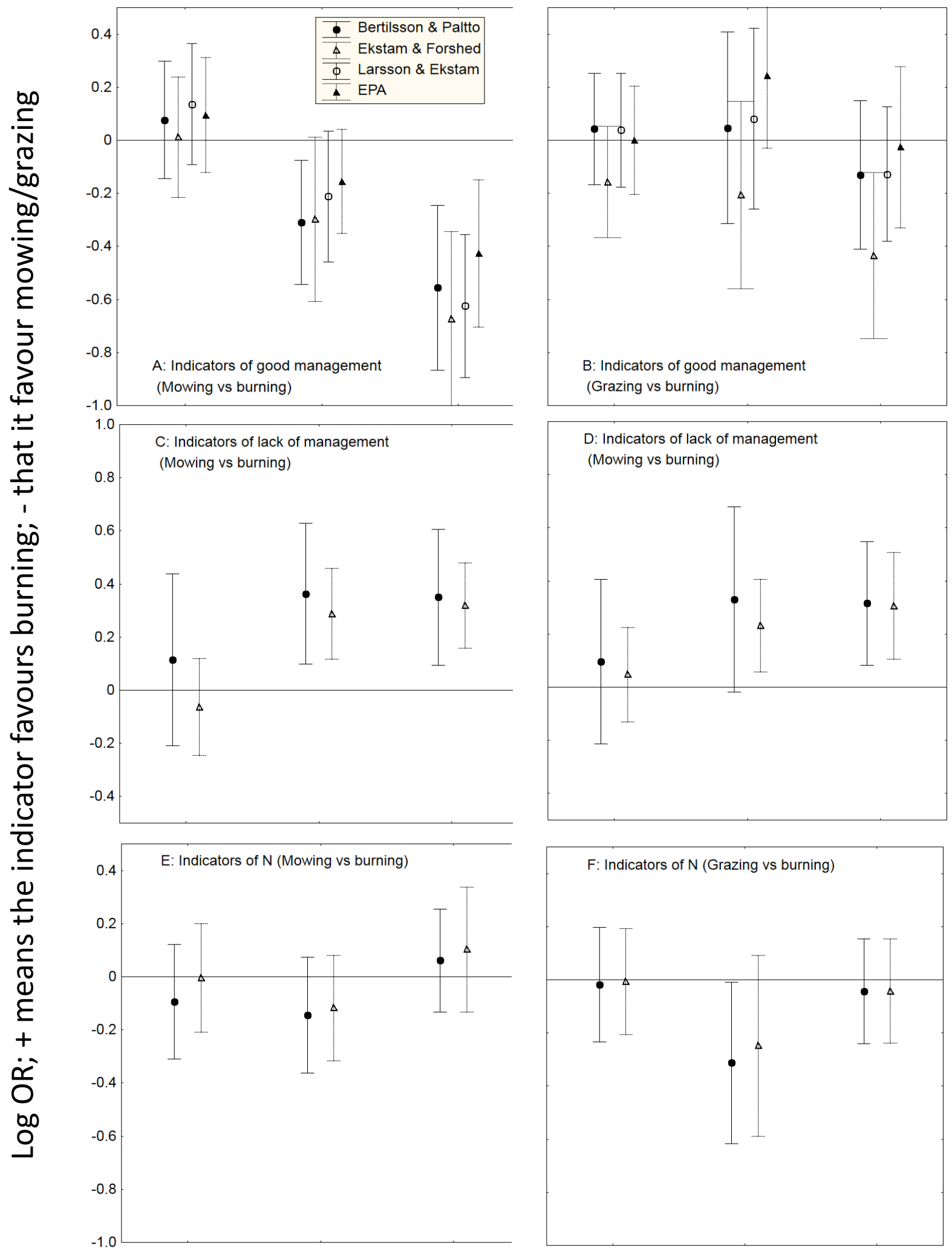

$D$ : Indicators of lack of management (Mowing vs burning)

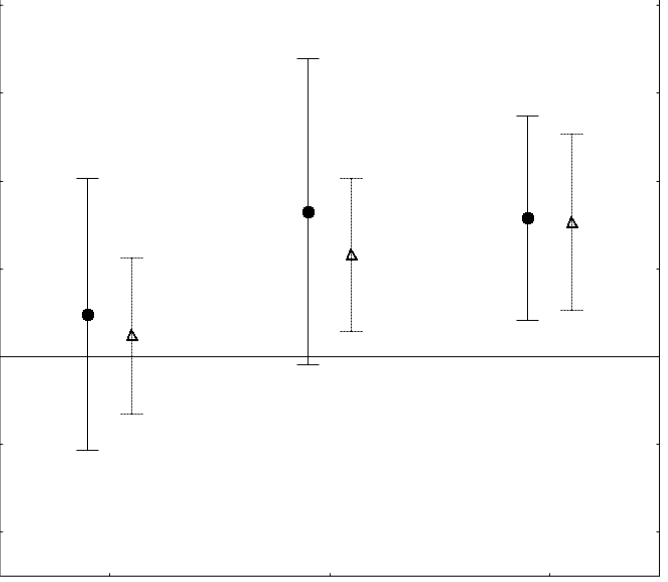

F: Indicators of N (Grazing vs burning)

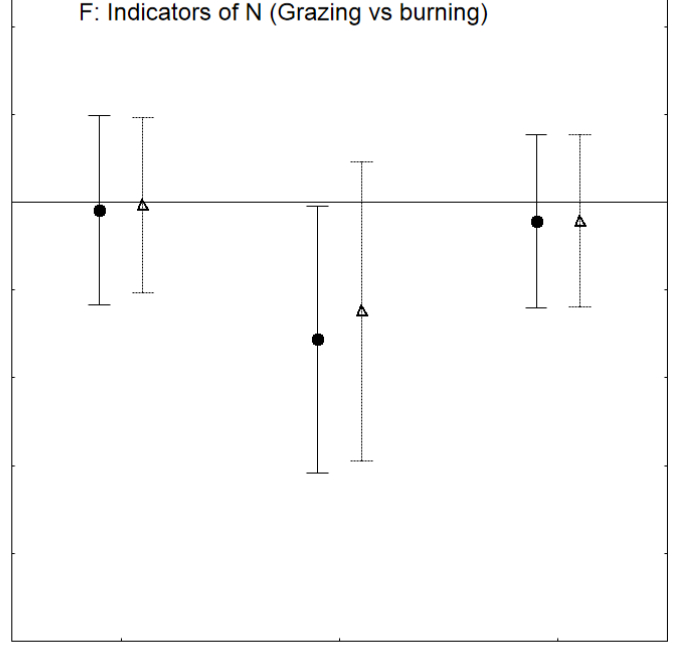

Fig. 2. Meta-analysis outcomes (Log OR) for the odds for indicator species versus non-indicator species in burnt plots compared with mowed plots and in burnt plots compared with grazed plots. Data were from 11 field trials in southern Sweden, each containing two independent blocks. Each treatment was sampled with a varying number of subplots. Eight different types of indicator species classifications were used. Error bars represent 95\% confidence intervals. 
The odds for the indicators of poor management were higher in burnt plots compared to the grazed and mowed plots (Fig. 2C, D), whereas the odds for the indicators of excess $\mathrm{N}$ showed no clear trend (Fig. 2E, F).

Meta-regression of the indicators of good management suggested that mowing and grazing led to an annual loss of -0.05 and -0.02 , respectively, when compared with burning (Table 3 ). Therefore, the differentiation in vegetation was slower when converting from grazing to burning than when mowing is used. The indicators of poor management, on the other hand, increased at a unit rate of 0.02 per year. No differences were observed when mowing and grazing were contrasted (Table 3 ). When examining the results from the indicator group with the clearest trend (Ekstam \& Forshed; Fig. 2A), it was apparent that the variability among trails was substantial (Fig. 3). The most extreme estimates were from species-poor areas (i.e., small symbols; Fig. 3). Nevertheless, the $\log$ OR in most trials decreased as the number of burns increased (Fig. 3).

Table 3. Slope estimates from the meta-regressions of the selected indicators. Values within parentheses are $95 \%$ confidence intervals.

\section{Burning vs mowing Burning vs grazing}

\begin{tabular}{lll}
\hline $\begin{array}{l}\text { Indicators of good } \\
\text { management } \\
\text { Bertilsson \& Paltto }\end{array}$ & $-0.048(-0.073 ;-0.024)$ & $-0.011(-0.035 ; 0.014)$ \\
$\begin{array}{l}2003 \\
\text { Ekstam \& Forshed }\end{array}$ & $-0.061(-0.086 ;-0.036)$ & $-0.024(-0.048 ; 0.0002)$ \\
$\begin{array}{l}1992 \\
\text { Larsson \& Ekstam }\end{array}$ & $-0.055(-0.081 ;-0.030)$ & $-0.011(-0.036 ; 0.015)$ \\
$\begin{array}{l}\text { 1987 } \\
\text { EPA 2011 }\end{array}$ & $-0.040(-0.063 ;-0.017)$ & $0.002(-0.025 ; 0.022)$ \\
$\begin{array}{l}\text { Indicators of poor } \\
\text { management } \\
\text { Bertilsson \& Paltto }\end{array}$ & $0.021(-0.010 ; 0.052)$ & $0.019(-0.011 ; 0.049)$ \\
$\begin{array}{l}\text { 2003 } \\
\text { Ekstam \& Forshed }\end{array}$ & $0.029(0.011 ; 0.044)$ & $0.022(0.004 ; 0.041)$ \\
1992 &
\end{tabular}




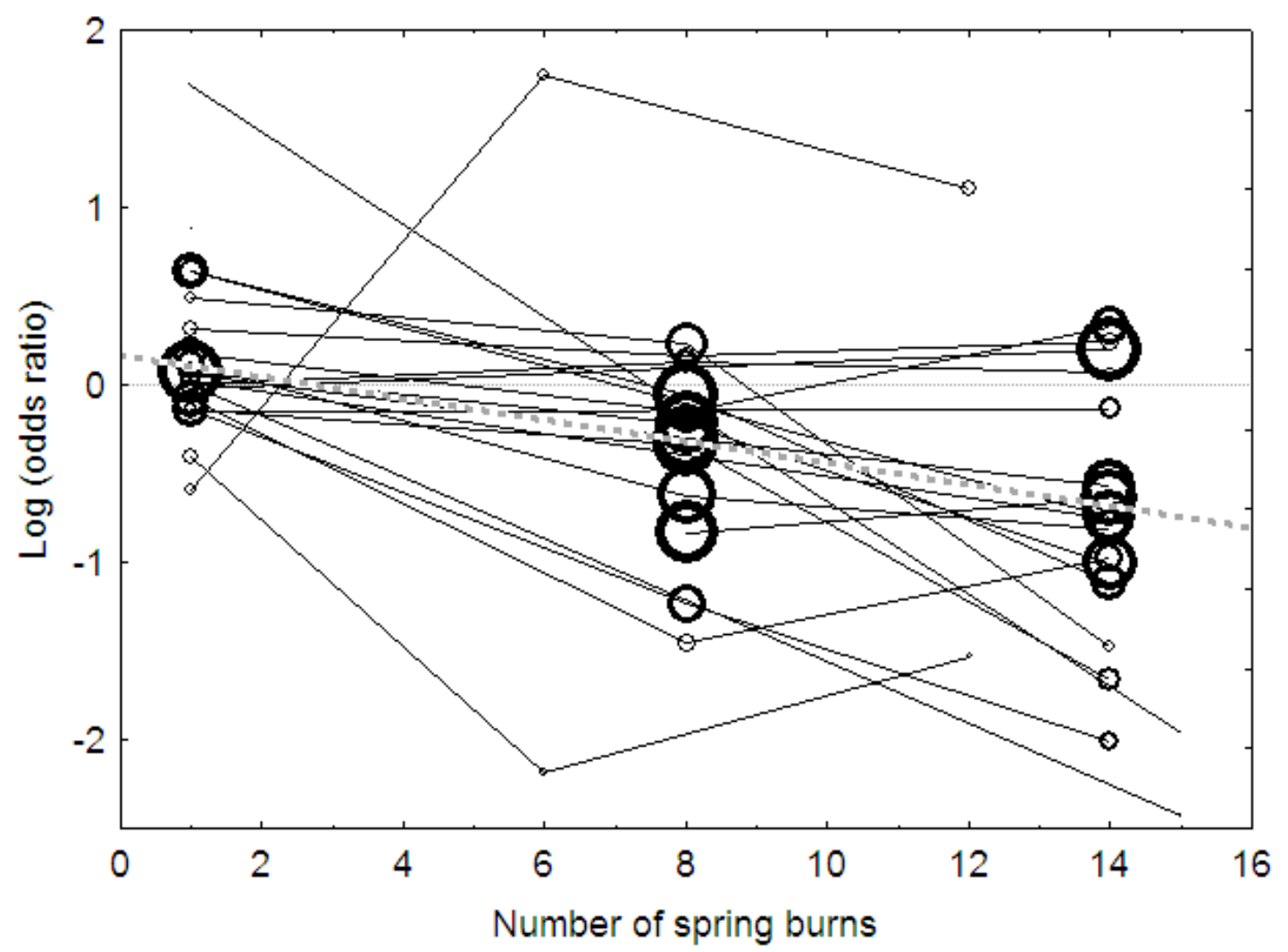

When the data from the 1986/7 follow-up were grouped (after 14 or 15 spring burns), it was apparent that the trials at the mesic sites showed the clearest difference between the burning treatment and the traditional methods (Fig. 4). The corresponding differences also existed at the two dry sites, but substantial confidence intervals were also observed. In contrast, no difference was observed between the two moist sites (Fig. 4; one moist sites had been excluded because it lacked the indicator species used). 


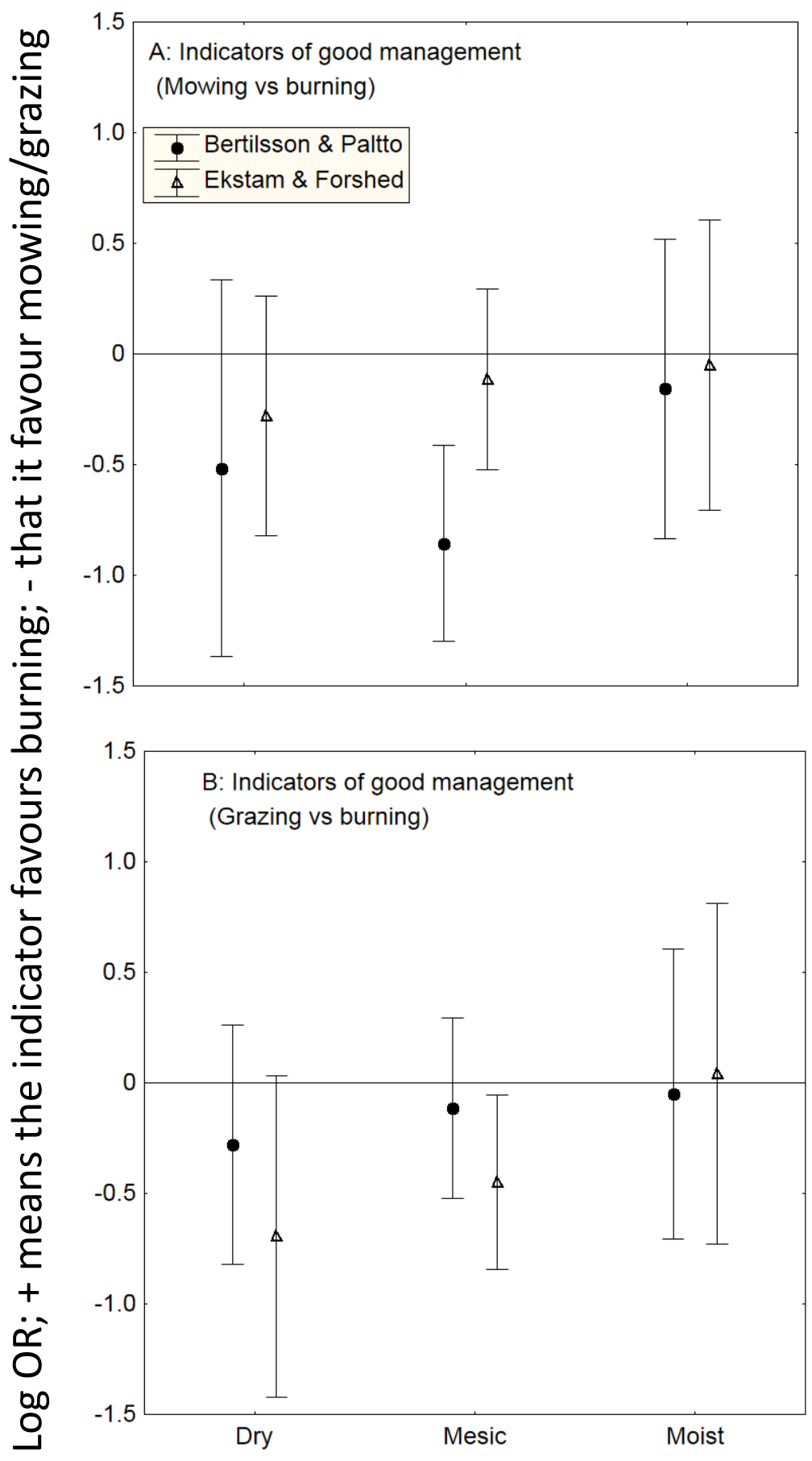

Fig. 4. Grouping of trials by the following vegetation types: dry, mesic, and moist grassland. Data are Log OR for the odds for the indicator species versus non-indicator species in burnt plots compared to mowed plots and in burnt plots compared to grazed plots. The analysis is based only on the inventory after 12-13 spring burns. Only the two indicators with the strongest signal (Fig. 2) are shown. Error bars represent 95\% confidence intervals. 


\section{Management outcome at the Sättra field trial}

Data were available for a longer time span (39 yrs) from a single block from a single trial. As expected, variability in the effect size estimates was larger and the patterns were less clear. Nevertheless, the odds for the indicators of good management decreased in the burning treatment compared with the traditional methods (Fig. 5A, B). There appeared to be a corresponding increase in the odds of the indicators of poor management (Fig. 5C, D). The temporal trend in both of these types of indicators is intriguing and suggests that a continued deterioration occurs for up to 14 spring burns, followed by a slight improvement that stabilises (Fig. 5A-D). The indicators of excess $\mathrm{N}$ displayed no clear patterns (Fig. 5E, F).

It is important to note that the data collected for the second block at Sättra were excluded from the analyses because the management failed around 1986. In this block, the burning treatment could not be executed due to invasions by Rubus idaeus and Aegopodium podagraria. These two dominant species had out-competed the grasses, resulting in a spring situation with little to zero combustible litter (personal observation in the spring of 2011 and an interview with the manager of the trial).

\section{Discussion}

\section{Spring burning cannot be recommended}

Our results showed that burning has a generally negative effect on the species that are indicators of good management and a positive effect on the grassland species that are indicators of poor management. The trend was very clear when comparing burning with mowing, but less so when compared with grazing. The latter could be attributed to the relatively low grazing pressure noted at many trials after 12-15 years (Hansson 1991) and later (personal observations). Therefore, burning cannot be recommended as an efficient long-term management alternative to mowing or grazing if the aim is to maintain a species-rich vegetation in the traditionally managed semi-natural grasslands. The level of evidence for this conclusion is strong (McArdle 1996; Balshem et al. 2011; Burns et al. 2011), as the meta-analyses were based on 11 replicated field trials. When comparing Figures 2 and 5, it is apparent that a single field trial provided weaker evidence (larger CI, a less clear trend). Adding to the strong level of evidence is the relatively long follow-up period of 14 or 15 spring burns. Given the rate of change (Table 3), it is hardly surprising that a recent study was unable to document vegetation shifts in a short-term follow up experiment (three spring burns; Larsson \& Persson 2012). 

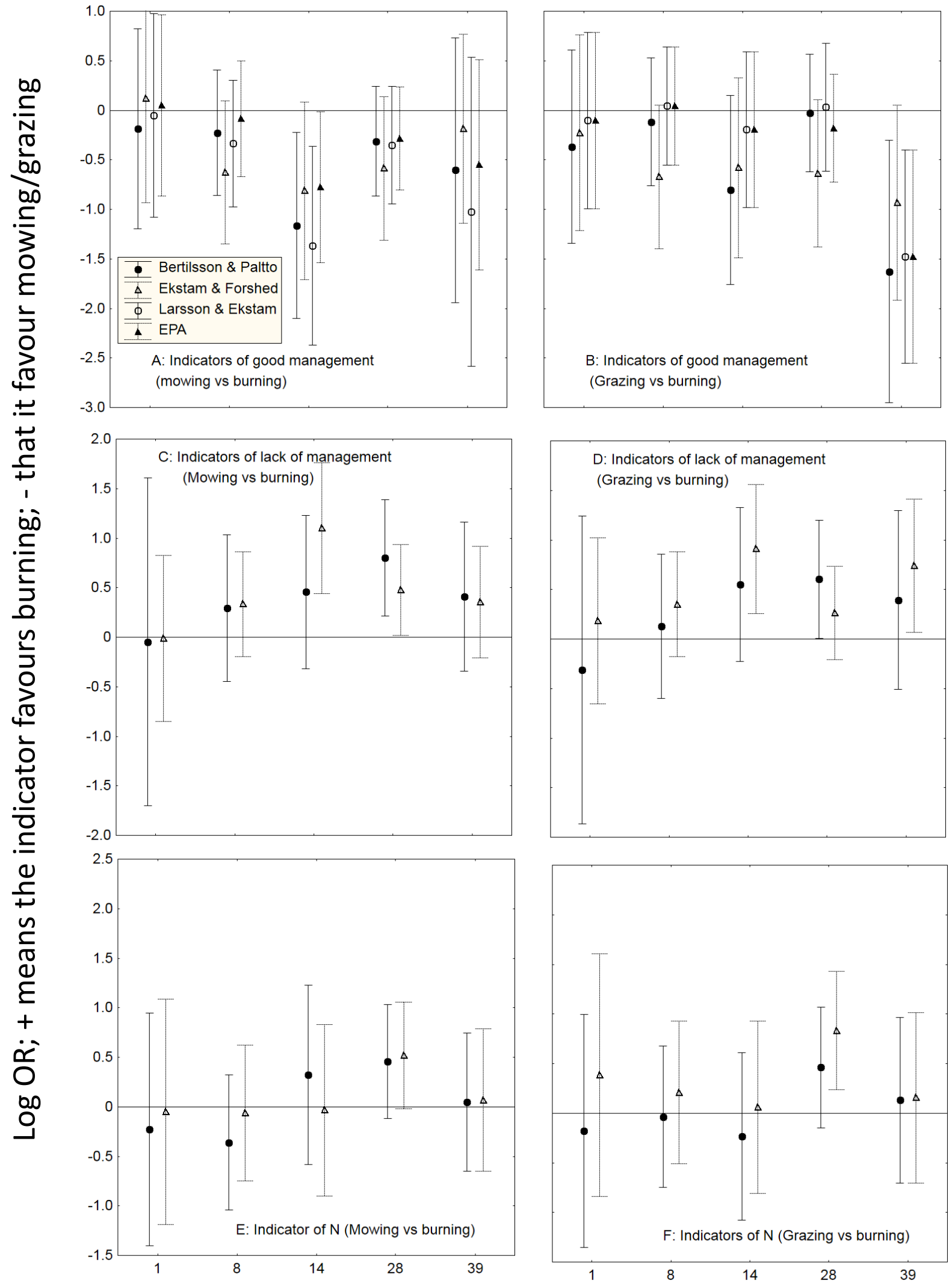

Fig. 5. Log OR for the odds for the indicator species versus non-indicator species in burnt plots compared to mowed plots and in burnt plots compared to grazed plots. Data were from the field trial at Sättra, from the only block for which data had been collected throughout the trial. Eight different types of indicator species classifications were used. Error bars represent $95 \%$ confidence intervals 
An additional observation from our trials adds further evidence that burning is not advisable: one of the two burnt treatment plots at Sättra (the only site with a long-term follow up; $39 \mathrm{yrs)} \mathrm{had} \mathrm{to} \mathrm{be} \mathrm{excluded} \mathrm{from}$ the analyses because it had been invaded by undesired species that prevented further burning. The undesired species, Aegopodium podagraria and Rubus idaeus, are unlikely to become dominant in mowed or grazed plots; their invasion points to a risk of treatment failure when a spring burning strategy is used.

It is worth pointing out that different types of grasslands may have different responses to spring burning; e.g. our moist grassland failed to show a response (Fig. 4).

\section{Comparisons with previous studies}

Data from two of the trials analysed here have previously been evaluated separately, by Hansson \& Fogelfors (2000; 14 yrs follow-up) and Wahlman \& Milberg (2002; 28 yrs follow-up). These authors reached conclusions similar to ours regarding burning; however, their conclusions were based on the richness of species in mown, grazed and burnt plots and on multivariate analyses of vegetation (where burnt plots stood out). There are of course many reasons why research finds are ignored by managers (e.g. Cook et al. 2013; McConnachie \& Cowling 2013), but in the present case one may speculate that multivariate analyses may not have conveyed clear messages to managers. We hope that the current focus on "evidence-based conservation" and our attempt to present odds ratios will facilitate communication with stakeholders and practitioners more successfully. We therefore strongly advocate the presentation of results, when appropriate, in the context of decision support for managers.

The previous studies with short-term follow-up periods (Antonsen \& Olsson 2005; Hermanova 2011; Larsson \& Persson 2012) are unlikely to show much effect from the treatments, judging from our results (cf. Fig. 5, Table 3), i.e., with a short-term follow-up, statistical power is low. There are at least two sets of trials with long-term follow-up periods with some relevance to Scandinavian conditions. In Switzerland, two trials that were maintained for 22 and 24 years were set up to compare abandonment, different mowing regimes, and spring burning (Ryser et al. 1995). Köhler et al. (2005) concluded from these replicated experiments that burning could not be recommended, mainly because of the strong increase in the presence of an undesired, dominating grass species (Brachypodium pinnatum). These authors also noted that the three replicate plots under traditional management remained uniform, while spring-burnt plots were variable and showed divergent tendencies 
(Köhler et al. 2005). In southern Germany, a number of grassland management trials started in the 1970s. These trials involved abandonment, grazing, different mowing regimes, and spring burning (Schreiber et al. 2009). One of these trials with a 25-yr follow-up period has been studied in detail (Kahmen et al. 2002; Kahmen \& Poschlod 2008; Moog et al. 2002, Drobnik et al. 2011). In the multivariate analyses, spring burning treatment yielded results that were substantially different from annual mowing or grazing treatments; the spring burning treatment mostly resembled the untreated control. Based on that trial, spring burning was not recommended as a management tool (Kahmen et al. 2002; Moog et al. 2002).

The actual mechanisms involved in the differentiation among treatments is less clear, though it is interesting to note that the productivity in burnt plots seem to increase compared with mowed plots (Ryser et al. 1995). This finding suggests a scenario with some resemblance to the addition of fertiliser, which is well known to reduce richness in species-rich grasslands (Socher et al. 2012). A spring burn is also likely to consume some of the seeds in the litter burnt, as well as create an open seed bed for spring-germinating species.

In conclusion, all of the European studies that are known to us and that contain a long-term follow-up period all point in the same direction: burning cannot be recommended if the aim is to preserve vegetation that is typical of the traditional methods of mowing or grazing.

\section{Possible benefits with spring burning}

Although it is clear that spring burning is not a long-term alternative to traditional mowing and grazing, there might be other considerations than the aim is to preserve a species-rich flora resembling that of traditional management. Burning might be valuable for eliminating accumulated litter (Hansson \& Fogelfors 2000), especially if management has failed in the previous year, or to prevent extensive spread of shrubs (Moog et al. 2002, Schreiber et al. 2009). It is also possible that burnt plots contain more flowers during the growth season than mowed or grazed plots, thus creating good conditions for nectar- and pollen-feeding insects (e.g., Larsson \& Persson 2012). If flower abundance is a management target in itself, it might be possible to create vegetation for that purpose through spring burning. The question remains, however, if those flower resources would persist over longer time periods. 
$N$ in the study system was unaffected by the treatments

We included indicators of excess $\mathrm{N}$ in our study, assuming that repeated burning might cause a loss of nitrogen into the atmosphere (e.g., Hobbs et al. 1991, Blair 1997, and Turner et al. 1997). However, none of the two indicators of excess $\mathrm{N}$ examined revealed any trends. If the loss of $\mathrm{N}$ was important for vegetation, it would be most pronounced when grazing and burning were compared, as the former involves substantial recirculation of $\mathrm{N}$ through the urine and faeces of grazing species (both burning and mowing would involve a loss of $\mathrm{N}$ ). As there has been substantial $\mathrm{N}$ deposition during the study period (e.g. Falkengren-Grerup et al. 1998; Malmer \& Wallen 2005) - open field deposition in southern Sweden was estimated to be $10-15 \mathrm{~kg} \mathrm{~N}^{-1} \mathrm{yr}^{-1}$ (Lövblad et al. 1995) - it is possible that there has been a general net gain in $\mathrm{N}$, even after the spring burning of dead litter (that has low N contents). Even so, we would still expect grazing to be the treatment with relatively more $\mathrm{N}$-indicators; however, this was not the case.

\section{What is the importance of indicator classification system?}

The indicators of good management seemed to carry the strongest signal. The effect sizes were larger and the trends were more pronounced in the results based on the two more management-specific indicator classifications (Bertilsson \& Paltto, Ekstam \& Forshed) compared with the two others (Fig. 2A, B), while the confidence intervals were similar in size. The choice of the indicator system may therefore influence the conclusions. Furthermore, the estimates of change are greatly influenced by the indicator classification systems (Table 3 ), which suggests that the effect sizes will be difficult to compare between the different contexts (i.e., experiments conducted in southern and northern Europe with very different floras and indicator species systems). Nevertheless, trends in the effect size may still add to the general conclusions and the transferability of results beyond individual experiments.

We had expected the sampling methodology to affect the precision of the effect size estimates (i.e., the size of the confidence intervals), and this was apparent in Fig. 5C-F, where the odds from the first survey (after 1 burn) were based on the treatment plots, while later experiments used five subplots. Furthermore, it seems that the follow-up after 28 years stands out (e.g., deviates from the trend; Fig. 5B, E, F); in this case, the inventory was done in the September, while the others were done in July. We therefore caution against merging data generated by vastly different methodologies. 
We also caution that the taxonomic ambition in the field may be different when data from different sources are merged. Skill in the identification of grasses, sedges, etc., may vary; therefore, the list of target species might vary, even when using the same indicator species system. In effect, this means that the potential indicator species present may not be noted or may be classified as non-indicators.

The effect sizes varied between the indicator systems, despite the relatively large overlap in species composition between them, demonstrating that there is room for improvement in the statistical power of this analysis, which can be achieved by optimising the species classifications.

\section{How large is the effect size?}

In studies that analyse vegetation using multivariate methods, it is difficult to present estimates of the effect sizes that are meaningful. By using odds ratios - contrasting the odds for an observation belonging to an indicator species - it is now possible to give meaning to the estimated effect sizes (Rita \& Komonen 2008). With a constant rate of change such as $-0.05 \log$ OR units per year (Table 3 ), we have lost 0.5 units in 10 years. Although this method is mathematically superior to ratios of probabilities (often called risk ratios), assigning a meaning to an odds ratio is more challenging (e.g., Katz 2006; Grimes \& Schulz 2008). If we are dealing with a rare phenomenon, then the two types of ratios are similar. The current study dealt with indicators that were relatively frequent, so interpreting changes in an odds ratio cannot be equated with a change in probability (Cummings 2009). Another way of assigning a meaning to an effect size measured as an odds ratio may be to convert the number to Cohen's d, i.e., a standardised effect size of a continuous variable (Borenstein et al. 2009). In the case of a difference of 0.5 units over a 10-year follow-up period, which is approximately what the indicators with the clearest patterns showed (Table 3), this result would correspond to $\mathrm{d}=0.28$. The difference between the control (grazing) and an alternative treatment (mowing) is $0.28 \mathrm{SD}$ units. In terms of metaanalysis, this is a relatively small effect (Cohen 1988). As the context in our study is rather unique (converting vegetation data to odds ratios with substantial variation between trials), more examples are needed before we can fully put the current effect size into perspective.

\section{Conclusions}

Spring burning cannot be recommended as an efficient long-term management alternative to maintain species-rich vegetation in traditionally managed semi-natural grasslands. 
Using the odds of a record being an indicator proved to be a useful way to summarise vegetation data from different sites and species compositions, and collected with different methodologies. Furthermore, the odds ratios and the meta-analysis proved to be an efficient way to analyse the treatment effects and to present the outcome. Absolute effect sizes, however, vary depending on the indicator system; therefore, the main focus should be on trends.

\section{Acknowledgements}

First and foremost, we thank all those involved in initiating, maintaining, managing, and monitoring the long-term field trials analysed here. The Swedish Environmental Protection Agency initially funded these trails. We thank Lars Westerberg, Najihah Musa, Sofia Nygårds, and Henrik Norman for comments. Antonin Leclercq helped collect data at Sättra in 2011. Financial support for our study was provided by "Stiftelsen Oscar \& Lili Lamms minne" and "Wala \& Folke Danielssons fond".

\section{References}

Antonsen, H. \& Olssson, P.A. 2005. Relative importance of burning, mowing and species translocation in the restoration of a former boreal hayfield; responses of plant diversity and microbial community. Journal of Applied Ecology 42: 337-347.

Balshem, H., Helfand, M., Schunemann, H.J., Oxman, A.D., Kunz, R., Brozek, J., Vist, G.E., Falck-Ytter, Y., Meerpohl, J., Norris, S. \& Guyatt, G.H. 2011. GRADE guidelines: 3. Rating the quality of evidence. Journal of Clinical Epidemiology 64: 401-406.

Bertilsson, A. \& Paltto, H. 2003. Hagar i Skaraborg år 2001: en återinventering med miljöövervakningssyfte. County Administration Board of Västra Götaland. 2003:15. http://www5.o.1st.se/pdf/rapport200315.pdf (accessed 5 August 2011)

Borenstein, M., Hedges, L.V., Higgins, J.P.T. \& Rothstein, H.R. 2009. Introduction to Meta-Analysis. John Wiley \& Sons, Ltd, Chichester, UK.

Blair, J.M. 1997. Fire, N availability, and plant response in grasslands: a test of the transient maxima hypothesis. Ecology 78: 2359-2368.

Burns, P.B., Rohrich, R.J. \& Chung, K.C. 2011. The levels of evidence and their role in evidence-based medicine. Plastic \& Reconstructive Surgery 128: 305-310. 
Cohen, J. 1988. Statistical power analysis for the behavioral sciences. $2^{\text {nd }}$ ed. Lawrence Erlbaum, Hillsdale, NJ.

Cook, C.N., Possingham, H.P., Fuller R.A., 2013. Contribution of systematic reviews to management decisions. Conservation Biology 27, 902-915.

Cummings, P. 2009. The relative merits of risk ratios and odds ratios. Archives of Pediatrics \& Adolescent Medicine 163: 438-445.

De Deyn, G.B., Shiel, R.S., Ostle, N.J., McNamara, N.P. Oakley, S., Young, I., Freeman, C., Fenner, N. Quirk, H. \& Bardgett, R.D. 2011. Additional carbon sequestration benefits of grassland diversity restoration. Journal of Applied Ecology 48: 600-608.

Drobnik, J., Römermann C, Bernhardt-Römermann, M. \& Poschlod, P. 2011. Adaptation of plant functional group composition to management changes in calcareous grassland. Agriculture, Ecosystems \& Environment 145: 29-37.

Ekstam, U. \& Forshed, N. 1992. Om hävden upphör; kärlväxter som indikatorarter $i$ ängs- och hagmarker. Naturvårdsverket Förlag, Solna.

Ekstam, U. \& Forshed, N. 1996. Äldre fodermarker: betydelsen av hävdregimen i det förgångna, målstyrning, mätning och uppföljning. Naturvårdsverket Förlag, Solna.

Ekstam, U. \& Forshed, N. 2000. Svenska naturbetesmarker: historia och ekologi. Naturvårdsverket Förlag, Solna.

EPA. 2011. Natura 2000: Gräsmarker. Vägledningar för gräsmarker, beslutade november 2011. Swedish Environmental Protection Agency http://www.naturvardsverket.se/Stod-i-miljoarbetet/Vagledningamnesvis/Natura-2000/Natura-2000-Grasmarker/ (accessed March 2013)

Falkengren- Grerup, U., Brunet, J. \& Diekmann, M. 1998. Nitrogen mineralization in deciduous forest soils in south Sweden in gradients of soil acidity and deposition. Environmental Pollution 102: 415-420

Fogelfors, H. 1982. Det marginella odlingslandskapets öppethållande. Del II. Resultat och utvärdering av långvariga försök med olika skötselmetoder. Swedish University of Agricultural Sciences. Department of Ecology and Environmental Research. Report No. 11, 83 pp.

Franzén, M. \& Nilsson, S.G. 2008. How can we preserve and restore species richness of pollinating insects on agricultural land? Ecography 31: 698.708 .

Grimes, D.A. \& Schulz, K.F. 2008. Making sense of odds and odds ratios. Obstetrics \& Gynecology 111: 423-426. 
Hansson, M. 1991. Management of semi-natural grassland. Results of a fifteen-year-old field experiment in south and central Sweden. Swedish University of Agricultural Sciences, Uppsala. Department of Ecology and Environmental Research. Report No. 45, 124 pp.

Hansson, M. \& Fogelfors, H. 2000. Management of semi-natural grassland; results from a 15-year old experiment in southern Sweden. Journal of Vegetation Science 11: 31-38.

Hermanova, M. 2011. Vliv obhospodařování na druhovou skladbu a funkční charakteristiky travních porostu. Thesis, Univerzita Palackého v Olomouci, http://theses.cz/id/zplavi/Diplomov prce.pdf

Hobbs, N.T., Schimel, D.S., Owensby, C.E. \& Ojima, D.S. 1991. Fire and grazing in the tallgrass prairie: contingent effects on nitrogen budgets. Ecology 72: 1374-1382.

Isselstein, J., Jeangros, B. \& Pavlu, V. 2005. Agronomic aspects of biodiversity targeted management of temperate grassland in Europe: a review. Agronomy Research 3: 139-151.

Jansson, N., Bergman, K.-O., Jonsell, M., Milberg, P. 2009. An indicator system for identification of sites of high conservation value for saproxylic oak (Quercus spp.) beetles in southern Sweden. Journal of Insect Conservation 13: 399-412.

Kahmen, S. \& Poschlod, P. 2008. Effects of grassland management on plant functional trait composition. Agriculture, Ecosystems \& Environment 128: $137-145$.

Kahmen, S., Poschlod, P. \& Schreiber, K.F. 2002. Conservation management of calcareous grasslands: changes in plant species composition and response of functional traits during 25 years. Biological Conservation 104: 319-328.

Karlsson, T. 1998. Förteckning över svenska kärlväxter. [The vascular plants of Sweden - a checklist.] Svensk Botanisk Tidskrift 91: 241-560.

Katz, K.A. 2006. The (relative) risks of using odds ratios. Archives of Dermatology 142: 761-764.

Köhler, B., Gigon, A., Edwards, P.J., Krüsi, B., Langenauer, R., Lüscher, A. $\&$, Ryser P. 2005. Changes in the species composition and conservation value of limestone grasslands in Northern Switzerland after 22 years of contrasting managements. Perspectives in Plant Ecology, Evolution and Systematics 7: 51-67.

Kumm, K.-I. 2003. Sustainable management of Swedish seminatural pastures with high species diversity. Journal for Nature Conservation 11: 117-125. 
Larsson, B.M.P. \& Ekstam, U. 1987. Inventering av ängs- och hagmarker: indikatorarter för hävdad och ogödslad mark. Swedish Environmental Protection Agency, Stockholm, 225 pp

Larsson, K. 2007. Bränning och markstörning gynnar hotade arter i Halland. [The use of fire and disturbance when preserving threatened species in Halland, SW Sweden.] Svensk Botanisk Tidskrift 101: 85-90.

Larsson, K. \& Persson, K. 2012. Naturvårdsbränning i gräsmarker: en jämförande studie av bete, bränning och slåtter 2010-2012. Report, Länsstyrelsen i Jönköpings län.

Lindborg, R. \& Eriksson, O. 2004. Effects of restoration on plant species richness and composition in Scandinavian semi-natural grasslands. Restoration Ecology 12: 318-326.

Lövblad, G., Kindbom, K., Grennfelt, P., Hultberg, H. \& Westling, O. 1995. Deposition of acidifying substances in Sweden. Ecological Bulletins 44: 17-34.

Malmer, N. \& Wallén, B. 2005. Nitrogen and phosphorus in mire plants: variation during 50 years in relation to supply rate and vegetation type. Oikos 109: 539-554.

McArdle, B.H. 1996. Levels of evidence in studies of competition, predation, and disease. New Zealand Journal of Ecology 20: 7-15.

McConnachie, M.M. \& Cowling, R.M. 2013. On the accuracy of conservation managers' beliefs and if they learn from evidence-based knowledge: A preliminary investigation. Journal of Environmental Management 128: 7-14.

Mengersen, K., Gurevitch, J. \& Schmid, C.H. 2013. Metaanalysis of primary data. In: Koricheva, J., Gurevitch, J. \& Mengersen, K. (eds.) Handbook of meta-analysis in ecology and evolution. pp 300-312. Princeton University Press, Princeton, USA.

Milberg, P. 1995. Seed bank after eighteen years of succession from grassland to forest. Oikos 72: 3-13.

Minns, A., Finn, J., Hector, A., Caldeira, M., Joshi, J., Palmborg, C., Schmid, B., Scherer-Lorenzen, M., Spehn, E. \& Troumbis, A. 2001. The functioning of European grassland ecosystems: potential benefits of biodiversity to agriculture. Outlook on Agriculture 30: 179-185.

Moog, D., Poschlod, P., Kahmen, S. \& Schreiber, K.F. 2002. Comparison of species composition between different grassland management treatments after 25 years. Applied Vegetation Science 5: 99-106. 
Öckinger, E. \& Smith, H.G. 2006. Semi-natural grasslands as population sources for pollinating insects in agricultural landscapes. Journal of Applied Ecology 44: 50-59.

Pullin, A.S. \& Knight, T.M. 2004. Support for decision making in conservation practice: an evidence-based approach. Journal for Nature Conservation 11: 83-90.

Rita, H. \& Komonen, A. 2008. Odds ratio: an ecologically sound tool to compare proportions. Annales Zoologici Fennici 45: 66-72.

Ryser, P. Langenauer, R \& Gigon, A. 1995. Species richness and vegetation structure in a limestone grassland after 15 years management with six biomass removal regimes. Folia Geobotanica \& Phytotax. 30: 157-167.

Schreiber, K.-F., Brauckmann, H.-J., Broll, G., Krebs, S. \& Poschlod, P. (eds.) 2009. Artenreiches Grünland in der Kulturlandschaft. 35 Jahre Offenhaltungsversuche Baden-Württemberg. Verlag Regionalkultur, Heidelberg.

Socher, S.A., Prati, D., Boch, S., Müller, J., Klaus, V.H., Hölzel, N., Fischer, M. (2012) Direct and productivity-mediated indirect effects of fertilization, mowing and grazing on grassland species richness. Journal of Ecology 100: 1391-1399.

Steen, E. 1976. Det marginella odlingslandskapets öppethållande. Dokumentation i långvariga försök med olika skötselmetoder. Lantbrukshögskolan, Avdelningen för ekologisk miljövård, Uppsala, 105 pp.

Sundh, L. 2009. Bränning som hävdmetod - 50 års bränning av en åkerholme på Falbygden. [Burning as a means of preserving grassland flora.] Svensk Botanisk Tidskrift 103: 249-252.

Sutherland, W.J. Pullin, A.S. Dolman, P.M. \& Knight, T.M. 2004. The need for evidence-basedconservation. Trends in Ecology \& Evolution 19: 305308.

Svensson, R. 1988. Floravård i jordbrukslandskapet. [Flora conservation in the Swedish agricultural landscape.] Svensk Botanisk Tidskrift 88: 458465.

Turner, C.L., Blair, J.M., Schartz, R.J. \& Neel, J.C. 1997. Soil N and plant responses to fire, topography and supplemental $\mathrm{N}$ in tallgrass prairie. Ecology 78; 1832-1843.

Wahlman, H. \& Milberg, P. 2002. Management of semi-natural grassland vegetation; evaluation of long-term experiment in southern Sweden. Annales Botanici Fennici 39: 159-166. 
Wrage, N. Strodthoff, J. Cuchillo, H. M. Isselstein, J. \& Kayser, M. 2011.

Phytodiversity of temperate permanent grasslands: ecosystem services for agriculture and livestock management for diversity conservation.

Biodiversity \& Conservation 20: 3317-3339. 
Appendix S1. Species recorded in the 11 field trials in 1986/87, with information of indicator classification

\begin{tabular}{|c|c|c|c|c|c|c|c|c|}
\hline & \multicolumn{4}{|c|}{ Indicators of good management } & \multicolumn{2}{|c|}{$\begin{array}{l}\text { Indicators of lack of } \\
\text { management }\end{array}$} & \multicolumn{2}{|c|}{ Indicators of excess $\mathrm{N}$} \\
\hline & & Ekstam & & & & & & \\
\hline & $\begin{array}{c}\text { Bertilsson } \\
\text { \& Paltto } \\
2003\end{array}$ & $\begin{array}{c}\& \\
\text { Forshed } \\
1992 \\
\end{array}$ & $\begin{array}{c}\text { Larsson \& } \\
\text { Ekstam } 1987\end{array}$ & EPA 2011 & $\begin{array}{c}\text { Bertilsson } \\
\text { \& Paltto } \\
2003\end{array}$ & $\begin{array}{c}\text { Ekstam \& } \\
\text { Forshed } \\
1992 \\
\end{array}$ & $\begin{array}{c}\text { Bertilsson } \\
\text { \& Paltto } \\
2003 \\
\end{array}$ & $\begin{array}{c}\text { Ekstam \& } \\
\text { Forshed } \\
1992 \\
\end{array}$ \\
\hline \multicolumn{9}{|l|}{ Acer platanoides } \\
\hline Achillea millefolium & & & & & & & & $x$ \\
\hline Achillea ptarmica & & & & & & $x$ & & \\
\hline Aegopodium podagraria & & & & & & & $x$ & \\
\hline Agrimonia eupatoria & & & & & & & & \\
\hline Agrostis canina & & $x$ & & & & & & \\
\hline Agrostis capillaris & & & & & & $x$ & & \\
\hline Agrostis gigantea & & & & & & & & $x$ \\
\hline Agrostis sp. & & & & & & & & \\
\hline Agrostis stolonifera & & & & & & & & $x$ \\
\hline Ajuga pyramidalis & $x$ & $x$ & $x$ & $x$ & & & & \\
\hline Alchemilla glauscencens & & $x$ & & & & & & \\
\hline Alchemilla sp. & & & & & & & & \\
\hline Alchemilla vulgaris coll. & & & & & & & & \\
\hline Alnus glutinosa & & & & & & & & \\
\hline Alopecurus pratensis & & & & & & & & $x$ \\
\hline Anemone nemorosa & & & & & & $x$ & $x$ & \\
\hline Anthoxanthum odoratum & $x$ & $x$ & $x$ & & & & & \\
\hline Anthriscus sylvestris & & & & & & & $x$ & $x$ \\
\hline Anthyllis vulneraria & & $x$ & & & & & & \\
\hline
\end{tabular}


Arabis hirsuta

Argentina anserina

Athyrium filix-femina

Barbarea vulgaris

Betula pendula

Betula pubescens

Bidens tripartita

Bistorta vivipara

Brachypodium pinnatum

Briza media

Calamagrostis canescens

Calluna vulgaris

Campanula patula

Campanula persicifolia

Campanula rapunculoides

Campanula rotundifolia ssp.

rotundifolia

Campanula trachelium

Cardamine pratensis

Carex acuta

Carex caryophyllea

Carex cespitosa

Carex disticha

Carex echinata

Carex flacca

Carex hirta

Carex montana 
Carex muricata

Carex pallescens

Carex panicea

$\mathrm{x}$

Carex pilulifera

Carex sp.

Carex spicata

Carum carvi

Centaurea scabiosa

Cerastium fontanum ssp.

vulgare

Chenopodium polyspermum

Cirsium arvense

Cirsium palustre

Cirsium vulgare

Comarum palustre

Convallaria majalis

Corylus avellana

Crepis praemorsa

Cynosurus cristatus

Dactylis glomerata

Danthonia decumbens

Deschampsia cespitosa

Deschampsia flexuosa

Dianthus deltoides 
Elytrigia repens

Epilobium angustifolium

Equisetum arvense

Equisetum sylvaticum

Festuca ovina

Festuca pratensis

Festuca rubra

Filipendula ulmaria

Filipendula vulgaris

Fragaria vesca

Fragaria viridis

Fraxinus excelsior

Galeopsis bifida

Galeopsis sp.

Galeopsis speciosa

Galium album

Galium boreale

Galium palustre

Galium uliginosum 
Gnaphalium sylvaticum

Gnaphalium uliginosum

Helianthemum nummularium

Helictotrichon pratense

Helictotrichon pubescen

Heracleum sphondylium

Hieracium sect. Hieracium

Hieracium sect. Tridentata

Hieracium sect. Vulgata

Hieracium sp.

Hieracium umbellatum

Hypericum maculatum ssp.

maculatum

Hypericum perforatum

Hypochoeris maculata

Inula salicina

Iris pseudacorus

Juncus bufonius

Juncus conglomeratus

Juncus effusus

Juniperus communis

Knautia arvensis

Lathyrus linifolius

Lathyrus pratensis

Leontodon autumnalis 
Leontodon hispidus

Leucanthemum vulgare

Linaria vulgaris

Linum catharticum

Lotus corniculatus

Luzula campestris

Luzula multiflora

Luzula pilosa

Luzula sp.

Lychnis viscaria

Lysimachia vulgaris

Lythrum salicaria

Maiathemum bifolium

Medicago lupulina

Melampyrum cristatum

Melampyrum pratense

Melampyrum sylvaticum

Melica nutans

Mentha arvensis

Molinia caerulea

Myosotis scorpioides

Myosotis arvensis

Myosotis laxa ssp.

baltica/caespitosa

Myosotis ramosissima

Myosotis sp.

Nardus stricta 
Persicaria amphibia

Persicaria hydropiper

Persicaria lapathifolia

Phalaris arundinacea

Phleum pratense

Pilosella lactucella

Pilosella officinarum

Pimpinella saxifraga

Pinus sylvestris

Plantago lanceolata

Plantago major

Plantago media

Platanthera bifolia

Poa compressa

Poa nemoralis

Poa palustris

Poa pratensis

Poa pratensis ssp. angustifolia

Poa trivialis

Polygala vulgaris

$x$

Potentilla erecta

Potentilla reptans

Potentilla thuringiaca 
Primula veris

Prunella vulgaris

Prunus spinosa

Pteridium aquilinum

Quercus robur

Ranunculus acris

Ranunculus auricomus

Ranunculus bulbosus

Ranunculus flammula

Ranunculus polyanthemos

Ranunculus repens

Rhamnus cathartica

Rhinanthus minor

Rosa canina

Rosa dumalis

Rosa sp.

Rubus idaeus

Rubus saxatilis

Rubus subg. Rubus sect.

Rubus

Rumex acetosa

Rumex crispus

Rumex longifolius

Salix aurita

Salix repens

Salix sp

Satureja acinos $\mathrm{x}$ 
Satureja vulgaris

Scorzonera humilis

Scrophularia nodosa

Scutellaria galericulata

Sedum acre

Sedum album

Sedum rupestre

Sedum telephium ssp.

maximum

Silene nutans

Solidago virgaurea

Sorbus aucuparia

Stachys palustris

Stellaria graminea

Stellaria media

Stellaria pallida

Succisa pratensis

Taraxacum sect. Ruderalia

Thalictrum flavum

Thalictrum simplex

Tilia cordata

Tragopogon pratensis

Trifolium hybridum

Trifolium medium

Trifolium pratense

Trifolium repens

Trollius europaeus 
Urtica dioica

Vaccinium myrtillus

Vaccinium oxycoccus

Vaccinium uliginosum

Vaccinium vitis-idaea

Valeriana officinalis

Veronica chamaedrys

Veronica officinalis

Veronica serpyllifolia

Veronica spicata

Vicia cracca

Vicia sepium

Viola canina

Viola hirta

Viola palustris

Viola riviniana

$\mathrm{x}$

$\mathrm{x}$ $\mathrm{x}$

Viola sp. 